\title{
PENGELOLAAN KEBUTUHAN SEKSUAL FRATER YANG MENJALANI PEMBINAAN DI SEMINARI TINGGI
}

\author{
Gabriella Dhiegnadya Arini Wiraganingrum ${ }^{1}$ \\ Agustina Engry ${ }^{2}$ \\ Fakultas Psikologi Universitas Katolik Widya Mandala Surabaya
}

\begin{abstract}
Abstraksi
Frater merupakan panggilan bagi laki-laki beragama Katolik yang memutuskan untuk mengabdikan hidupnya hanya kepada Tuhan dan tinggal di dalam Seminari hingga akhir hidupnya. Frater harus secara sukarela meninggalkan setiap kehidupan duniawinya dan menaati nasihat injili. Penelitian ini bertujuan untuk mengeksplorasi bagaimana cara untuk mengelola kebutuhan seksual yang muncul pada frater yang menjalani pembinaan di Seminari Tinggi. Kebutuhan seksual adalah perilaku seksual yang muncul melalui perasaan atau keinginan erotis, gairah, dan fantasi seksual yang dirasakan oleh individu yang bersangkutan. Pada fase perkembangan genital, hormon seksualitas semakin matang dan dianggap siap untuk menyalurkan kebutuhan seksual muncul, tidak terkecuali pada frater. Peneliti tertarik untuk mengetahui bagaimana pengelolaan kebutuhan seksual frater yang menjalani pembinaan di Seminari Tinggi. Penelitian ini menggunakan metode fenomenologi, melalui proses wawancara semi-struktur pada dua frater yang berusia 19-30 tahun dan sudah menjalani pembinaan di Seminari Tinggi minimal 1 tahun. Teknik analisis yang digunakan adalah teknik induktif, dengan melakukan validitas komunikatif dan argumentatif. Hasil analisis data menunjukkan bahwa ada beberapa cara yang mendukung pengelolaan kebutuhan seksual, yaitu mengalihkan dorongan seksual yang muncul dengan melakukan kegiatan lain. Motivasi panggilan menjadi seorang Imam, keyakinan yang dimiliki untuk mengelola kebutuhan seksual dan pandangan mengenai kebutuhan seksual juga membantu pengelolaan kebutuhan seksual yang muncul selama pembinaan di Seminari Tinggi.
\end{abstract}

Kata kunci: pengelolaan kebutuhan seksual, frater, Seminari Tinggi

Frater is a call for Catholic men who decided to devote their lives to God. Live as a frater requires them to live in Seminary until the end of their live, so they must voluntarily leave every worldly life outside of Seminary and obey evangelical advice. This aim of this study is to explore how to manage sexual needs that appears on the live coaching frater at the Seminary. Sexual needs are sexual behaviors that arise through erotic feelings, desires, and sexual fantasies perceived by the individual concerned. On the development of the genital phase, hormones and sexuality are increasingly mature and considered ready to channel the sexual needs arise, no exception on frater. Therefore, researchers are interested in knowing how the management of sexual needs frater undergoing coaching at the High Seminary. This study is using Phenomenology method, and also through a semi-structured interview process. This study involve two frater who was 19-30 years old and already undergoing coaching in the High Seminary of at least 1 year. This study also using inductive thematic analysis, using communicative and argumentative validation. The results of the analysis of the data shown that there were several ways that support sexual needs, namely diverting sexual drive that arise by carrying out other activities. In addition, the motivation to be a priest, the confidence to manage sexual needs and views on sexual need also help manage the sexual needs that arise during coaching at the High Seminary.

Key words: Management of sexual need, frater, High Seminary 


\section{Pendahuluan}

Manusia adalah insan yang berakal budi dan memiliki kebebasan untuk memilih. Setiap manusia bebas untuk memilih sesuatu yang menjadi pilihan atas hidupnya dan memaknai setiap pilihan yang telah diambil. Manusia akan selalu dihadapkan kepada pilihan, salah satunya adalah pilihan untuk melanjutkan hidup. Beberapa orang memilih untuk menikah atau mungkin hidup melajang, namun beberapa orang memilih untuk menyerahkan hidupnya kepada Tuhan dengan menjadi biarawan. Dalam agama tertentu, seperti agama Katolik dan juga Buddha, istilah biarawan kerap kali muncul. Dalam agama Katolik sendiri, istilah biarawan dapat dikenal dengan frater (dari bahasa Latin yang berarti 'saudara laki-laki'). Beberapa laki-laki yang telah memilih untuk menjadi seorang frater akan menjalankan kehidupannya sebagai rohaniawan dan mengikuti aturan-aturan yang ditetapkan di Biara atau Seminari. Menurut Kitab Hukum Kanonik (KHK; KWI, 2016: 187), seorang frater dituntut untuk belajar menghayati tiga nasehat injili selama menjalani pembinaan di Seminari. Pertama, kemurnian, yang tidak memperbolehkan frater untuk menikah atau memiliki istri (hidup selibat) selama masa hidupnya. Tujuannya, agar frater memiliki hati yang murni dan tidak terbagi. Kedua, ketaatan, yakni setiap orang yang sudah memutuskan untuk menjadi seorang frater harus tunduk pada otoritas atau peraturan yang diberikan oleh Gereja dan biara atau seminari, sembari tetap mengikuti Kristus sampai mati. Yang ketiga adalah kemiskinan, yang berarti para frater diwajibkan memiliki kehidupan yang sederhana namun penuh semangat, sekaligus menjauhi kekayaan duniawi yang berlebihan. Dari hukum-hukum yang dikutip dari Kitab Hukum Kanonik, jelas bahwa hal-hal tersebut membatasi para frater untuk memaknai hidupnya seperti orang-orang pada umumnya, misalnya menikah, bebas, dan menikmati kekayaan (Charlys \& Kurniati, 2007: 34).

Saat berada di Seminari Tinggi,para frater tersebut akan memasuki tahap pendidikan dan penempaan kehidupan rohani yang lebih dalam lagi. Para frater akan menempuh pendidikan jenjang Perguruan Tinggi di Universitas yang notabene terdiri dari beragam individu yang berasal dari latar belakang yang berbeda. Tidak menutup kemungkinan bahwa para frater akan bertemu serta berinteraksi dengan banyak orang, tidak terkecuali lawan jenis. Frater yang memasuki Seminari Tinggi akan berada dalam tahapan rentang kehidupan masa dewasa awal (Santrock, 1999: 23). Menurut Harvinghurst (dalam Hurlock, 1996: 9), saat seseorang memasuki tahap rentang suatu kehidupan, maka akan ada tugas perkembangan yang harus terpenuhi.Salah satu tugas masa dewasa awal yang harus terpenuhi adalah memilih pasangan, baik pasangan hidup maupun seorang kekasih (Hurlock, 1996: 10).Ketiga nasihat injili tersebut merupakan suatu kewajiban yang harus dilakukan, ditaati, dan dihayati oleh setiap frater yang menjalani pilihan hidupnya, meskipun tidak mudah untuk menjalaninya. Kehidupan perkuliahan yang dijalani, interaksi dengan lawan jenis, serta pembinaan hidup rohani yang lebih dalam bukanlah suatu hal yang mudah untuk dilakukan dan dihayati oleh masing-masing frater. Hal tersebut merupakan suatu kewajiban, tetapi seorang frater juga manusia biasa yang sama seperti manusia lainnya. Mereka juga mengalami dan merasakan dorongan kenikmatan duniawi dengan berbagai macam kebutuhan, salah satunya adalah kebutuhan seksual.

Seksualitas atau sexuality berasal dari kata 'seks' dan memiliki banyak makna. Seks juga dapat diartikan menjadi jenis kelamin milik laki-laki atau perempuan. Seks juga dapat diartikan sebagai organ seksual yang berperan dalam proses reproduksi dan kenikmatan seksual saat berhubungan seks. Istilah seks juga berkaitan dengan perasaan, pengalaman, atau keinginan erotis, seperti fantasi dan pemikiran seksual, dorongan seksual, atau ketertarikan seksual (Rathus, Nevid \& Rathus, 2011: 4). Kebutuhan seksual secara umum akan muncul dan dialami oleh semua manusia, termasuk pada frater. Adanya nasihat injili yaitu kemurnian yang menuntut frater untuk hidup secara selibat, maka seorang frater harus dapat mengelola dan mengatasi kebutuhan seksualnya. Suparno (2007:11) menjelaskan bahwa beberapa 
biarawan sangat takut dengan hal-hal yang berbau seks; mereka alergi dengan seksualitas, dan mencoba bersikap dingin. Mereka juga beranggapan jika ingin menjadi biarawan yang suci, mereka harus melepaskan hal-hal yang berbau seks. Hal tersebur tersirat dalam kutipan wawancara preliminary yang dilakukan pada salah satu frater yang sedang menjalani pembinaan tahun ketiga di Seminari Tinggi. Berikut adalah kutipan wawancara dengan salah satu frater:

"Kalo secara seksual terangsang yo pernah, ya namanya manusia wajar pasti ada. Nek liat cewek yo pasti onok dorongan. Yo pengen berhubungan intim. Tapi ya nda sampe. Karena pas iku aku ngiling maneh, ngilingno posisiku, ngenengene sebagai frater. Kadang yo doa. Kadang nek aku kadang stress, nek stress ngono, misal e banyak tekanan ngono, misal e bari diseneni, paper durung mari, terus iki enek opo, enek opo, yo jeneng wong mesti yo butuh pelarian to. Ya itu yang membuat pikiran, yo kadang pengen onani. Kadang yo muncul perasaan ingin berhubungan intim, tapi ya nda dilakukan."

Berdasarkan hasil wawancara tersebut, dapat disimpulkan bahwa nyatanya dorongan untuk memenuhi kebutuhan seksual pasti ada pada seorang frater yang berfokus untuk hidup selibat. Informan menyadari bahwa dirinya membutuhkan dorongan untuk memenuhi kebutuhan seksualnya dan tidak menganggap bahwa keinginannya tersebut sebagai sesuatu yang salah. Dalam tatanan religius, Suparno (2006: 38) menyatakan bahwa terdapat beberapa cara yang dapat dilakukan untuk mengelola kebutuhan seksual, yaitu dengan membangun kesadaran, penerimaan diri secara penuh syukur, menerima seksualitas dengan pengertian yang tepat; membangun relasi yang dalam dengan diri sendiri, Tuhan, orang lain; mengembangkan relasi doa dengan Tuhan; mengembangkan cinta, intimacy, kegembiraan dalam hidup panggilan; membangun kasih dalam komunitas; setia pada komitmen utama; dan menyadari batas-batas ungkapan seksualitasnya.

Penelitian yang dilakukan oleh Pranoto (2014) mengenai pengelolaan kebutuhan seksual biarawati yang tetap mempertahankan kaul kemurniannya memiliki hasil analisis bahwa ada beberapa hal yang mendukung pengelolaan kebutuhan seksual secara tepat, yakni motivasi, kepribadian individu, keyakinan dan pandangan mengenai kaul kemurnian dan kebutuhan seksual, juga pengalaman selama masa pembinaan yang membuat para biarawati tetap mempertahankan kaul kemurniannya. Motivasi yang mendukung para biarawati dalam memilih keputusan hidup selibat berasal dari internal dan eksternal, seperti dukungan orang tua dan pimpinan biara, akan mempengaruhi bagaimana biarawati menghayati kehidupannya di biara dan mengatasi pergumulan yang dihadapi (termasuk tantangan dalam pengelolaan kebutuhan seksual).

Apabila fenomena kebutuhan seksual ini dikaitkan dengan teori dan penelitian di atas, maka hal ini termasuk normal. Hal ini dikarenakan setiap manusia akan merasakan dorongan seksual. Selain itu, masing-masing individu termasuk frater, dapat mengatasi atau mengelola pemenuhan kebutuhan seksual tersebut secara tepat dengan cara masing-masing. Implikasinya, apabila kebutuhan seksual tersebut tidak diatasi dengan tepat, hal itu dapat menjadi tantangan bagi para frater dalam menjalankan komitmennya pada nasihat injili kemurnian, terutama dalam kehidupan sehari-hari sebagai mahasiswa dan rohaniawan. Selain itu, pemahaman mengenai pengelolaan kebutuhan seksual yang efektif dan tepat bagi diri sendiri akan sangat membantu para frater untuk dapat selalu menjaga komitmen kemurniannya dan tidak keliru dalam pengelolaan kebutuhan seksualnya.

Freud merupakan salah satu tokoh psikologi yang berasal dari Austria dan pertama kali mengeluarkan teori psikoseksual pada tahun 1900. Konsep psikoseksual tersebut muncul atas dasar pikiran Freud bahwa setiap tahap perkembangan yang dilalui oleh manusia sejak kecil hingga dewasa akan mempengaruhi karakter orang itu sendiri (Feldman, 2011: 468). Fase 
perkembangan menurut Freud terdiri dari lima fase (Feldman, 2011: 469). Fase pertama adalah fase oral (0-12 bulan). Selama fase ini, seorang anak akan mulai melakukan beberapa aktivitas yang berkaitan dengan bagian oral atau mulutnya, seperti menghisap,dan menggigit apapun yang dapat dimasukkan ke dalam mulutnya.

Fase perkembangan yang kedua adalah fase anal (12 bulan-3 tahun). Anak akan merasakan kenyamanannya melalui toilet training yang dilakukan pada fase ini. Fase yang ketiga adalah fase phallic (sekitar 3 tahun ke atas). Fase ini seringkali dihubungkan dengan teori oedipal conflict, ketika anak laki-laki akan lebih tertarik pada ibunya dan merasa tersaingi oleh ayahnya, sedangkan anak perempuan akan lebih tertarik pada ayahnya dan merasa tersaingi oleh ibunya. Fase perkembangan yang ke empat adalah fase laten (6 tahunpubertas). Pada fase ini, ketertarikan seksualitas tidak terlalu diabaikan, bahkan terpendam di alam bawah sadar. Fase yang terakhir adalah fase genital (dewasa-seterusnya) Perasaan akan seksualitas yang telah diabaikan pada fase sebelumnya, muncul kembali pada fase genital, yang merupakan fase terakhir dari kehidupan seseorang sampai meninggal. Fokus dari fase ini adalah semakin matangnya hormon-hormon seksualitas dan alat reproduksi manusia, yang diartikan Freud bahwa manusia sudah siap untuk menyalurkan kebutuhan seksualnya dengan melakukan hubungan intim.

Laki-laki dapat terangsang secara seksual oleh berbagai rangsangan, termasuk rangsangan taktil yang dilakukan oleh pasangan mereka, rangsangan visual, atau fantasi seksual. Terlepas dari sumber rangsangan, respons seksual pria, ereksi, dan ejakulasi dapat terjadi secara refleks (Rathus, Nevid \& Rathus, 2011: 121). Hormon seksual pria diketahui mempengaruhi dorongan seks dan respon seksual pada pria (Bialy \& Sachs, 2002; Cooke et al., 2003, dalam Rathus, Nevid \& Rathus, 2011: 145). Gairah seksual juga dapat dipengaruhi oleh salah satu bagian otak, yang disebut korteks serebral (cerebral cortex). Ketika seorang laki-laki memikirkan aktivitas seksual, gambar, keinginan, dan fantasi seksual, maka sel yang ada di dalam korteks serebral akan menafsirkan informasi sensorik tersebut untuk mengaktifkan atau mematikannya. Sel ini akan mengirim pesan melalui saraf tulang belakang yang mengirimkan darah ke alat genital dan akhirnya menimbulkan ereksi. Setelah hal ini terjadi, korteks serebral pun juga dapat berfungsi untuk menyadarkan apakah aktivitas seksual tersebut merupakan sesuatu yang tepat atau tidak tepat, dapat menenangkan atau membuat semakin cemas, dan menimbulkan perasaan bersalah atau kepuasan (Rathus, Nevid \& Rathus, 2011: 142).

Prasetya (1992: 199) menyatakan bahwa terdapat beberapa cara sebagai kompensasi yang umumnya dilakukan manusia untuk mengelola kebutuhan psikologis terkait dengan kehangatan dan kepuasan seksual, khususnya biarawan. Beberapa di antaranya adalah dengan melakukan kegiatan lain yang positif, seperti berolahraga, memelihara dan merawat anjing, dan cara-cara lain yang dapat dilakukan sesuai minat para biarawan. William Kraft dalam Celibate Loving, Encounter in Three Dimensions (dalam Suparno, 2007: 83-89), menyatakan bahwa setiap manusia memiliki dorongan seksual, namun tidak harus untuk mengungkapkan dorongan itu secara badaniah. Kraft menjelaskan adanya lima cara untuk menghadapi dorongan seksual dalam dirinya. Cara yang pertama adalah represi. Secara sederhana, represi mengesampingkan pengalaman seksual dari kesadarannya dengan cara menekan perasaan seksual yang ada, seakan-akan tidak terjadi dalam dirinya. Represi ini bersifat negatif, dapat menimbulkan stress, menjadikan orang mudah marah, merasa sakit, atau kadang dapat menjadikan orang menjadi sedih sendiri dalam komunitas. Represi ini menolak kenyataan bahwa kita manusia yang seksual. Kita menolak bahwa kita diciptakan Tuhan dengan tubuh seksual.Cara kedua yang dapat dilakukan adalah supresi. Cara ini seperti represi, tetapi dengan kesadaran dan pilihan. Orang mengatakan 'tidak' pada sesuatu yang sebenarnya 'ya'. Supresi ini kadang disebut mortifikasi, mematikan sesuatu dalam diri kita, demi suatu nilai yang lain. Ia tetap seksual, tetapi tidak mau menyalurkannya. Cara ketiga yang dapat 
dilakukan untuk menghadapi dorongan seksual adalah sublimasi. Sublimasi adalah tindakan mengarahkan dorongan seksual kepada suatu tindakan atau kegiatan yang lain, seperti kerja, melakukan karya sosial, seni, dan sebagainya. Biasanya, tindakan sublimasi dilakukan karena bertentangan dengan nilai yang ingin dikejar.

Cara keempat yang dapat dilakukan adalah gratifikasi atau pelampiasan. Orang melampiaskan dorongan seksualnya dengan cara melakukan pemuasan secara fisik seperti masturbasi, sanggama, dan sebagainya. Pemuasan ini sering dipakai untuk mengurangi loneliness, kekosongan, dan kesepian. Sesudahnya, kekosongannya akan semakin bertambah, dan muncul rasa bersalah. Bagi kaum biarawan-biarawati, cara ini jelas tidak baik dan tidak sehat karena tidak mengembangkan pribadi secara menyeluruh. Cara kelima adalah integrasi. Menurut Kraft, supresi dan sublimasi cara yang penting secara psikologis untuk menghadapi dorongan seksual. Kelemahan dari cara ini adalah tetap memandang dorongan seksual atau genitalia secara fisik saja, padahal genitalia mempunyai segi lain yang perlu diperhatikan pula. Maka, Kraft menyarankan adanya integrasi yang bernilai, yaitu mengalami genitalia atau dorongan seksual sebagai suatu gejala yang membuka seluruh pribadi manusia. Integrasi berarti melihat dorongan seks sebagai manifestasi seluruh pribadi manusia. Dengan munculnya dorongan itu, kita diundang untuk melihat dimensi yang lebih dalam dari diri kita dan orang lain. Cara terakhir yang dapat dilakukan adalah menerima sebagai persembahan kepada Tuhan. Banyak biarawan-biarawati dalam praktek hidup membiara, mengatasi dorongan seksual yang kadang muncul dengan mempersembahkan dorongan itu kepada Tuhan sambil bertahan dalam tekanan dorongan tersebut. Mereka sadar bahwa mereka akan sering mengalami dorongan seksual itu seperti setiap orang mengalaminya. Mereka dapat mensyukuri dorongan itu karena menjadi tanda bahwa mereka ternyata memang manusia yang normal. Mereka juga menyadari bahwa pilihan hidup membiara, memang tidak mau menyalurkan dorongan itu secara badani lewat hubungan seksual. Maka dorongan itu disadarinya sebagai sesuatu yang memang dipersembahkan kepada Tuhan sekaligus bertahan dalam situasi dorongan ini, akhirnya dorongan itu secara alamiah juga hilang sendiri.

Penelitian ini berfokus pada bagaimana cara frater yang menjalani pembinaan di Seminari Tinggi mengelola kebutuhan seksualnya. Kebutuhan seksual yang dimaksudkan disini adalah kebutuhan yang muncul saat menjalani pembinaan di Seminari Tinggi dan menempuh pendidikan di Universitas yang notabene akan berinteraksi dengan lawan jenis Tujuan penelitian ini adalah untuk mengeksplorasi bagaimana cara untuk mengelola kebutuhan seksual yang muncul pada frater yang menjalani pembinaan di Seminari Tinggi. Peneliti mengangkat topik ini sebagai penelitian dan berharap topik ini dapat memberikan sumbangsih literatur untuk memperkaya kajian tentang pengelolaan kebutuhan psikologis, khususnya seksualitas pada frater.

\section{Metode Penelitian}

Penelitian ini menggunakan metode penelitian kualitatif dengan tipe penelitian yang digunakan dalam penelitian ini adalah fenomenologi. Pendekatan fenomenologi merupakan sebuah studi yang berusaha untuk mendeskripsikan dan berusaha mencari "esensi" makna dari suatu fenomena yang dialami oleh beberapa individu (Creswell, 2013: 94). Tujuan dari fenomenologi adalah untuk mereduksi pengalaman individu pada fenomena dan deskripsi tentang esensi atau intisari yang universal. Dengan demikian, peneliti dapat mengetahui gambaran pengalaman individu, khususnya frater, terkait sebuah fenomena yang dialami yaitu pengelolaan kebutuhan seksual.

Karakteristik informan dalam penelitian ini adalah frater yang menjalani pembinaan di Seminari Tinggi minimal 1 tahun dan berusia sekitar 19-30 tahun ke atas. Penelitian ini menggunakan dua informan yang memiliki tingkat pembinaan yang berbeda. Metode pengumpulan data dalam penelitian ini adalah wawancara semi-terstruktur. Pengambilan data 
dilakukan selama 2 bulan dengan durasi wawancara sekitar satu jam. Teknik analisis data yang digunakan oleh peneliti adalah inductive thematic analysis. Pengumpulan data yang objektif dalam penelitian kualitatif memerlukan standarisasi berupa validitas penelitian. Terdapat dua cara yang dilakukan untuk memvalidasi data penelitian, yaitu dengan mengkonfirmasi kembali data verbatim serta analisis pada informan (validitas komunikatif) dan memastikan temuan serta kesimpulan penelitian dapat dipahami secara rasional (validitas argumentatif). Peneliti juga membandingkan hasil penelitian dengan data lain yang dimiliki oleh informan berupa buku harian.

\section{Hasil Penelitian dan Diskusi}

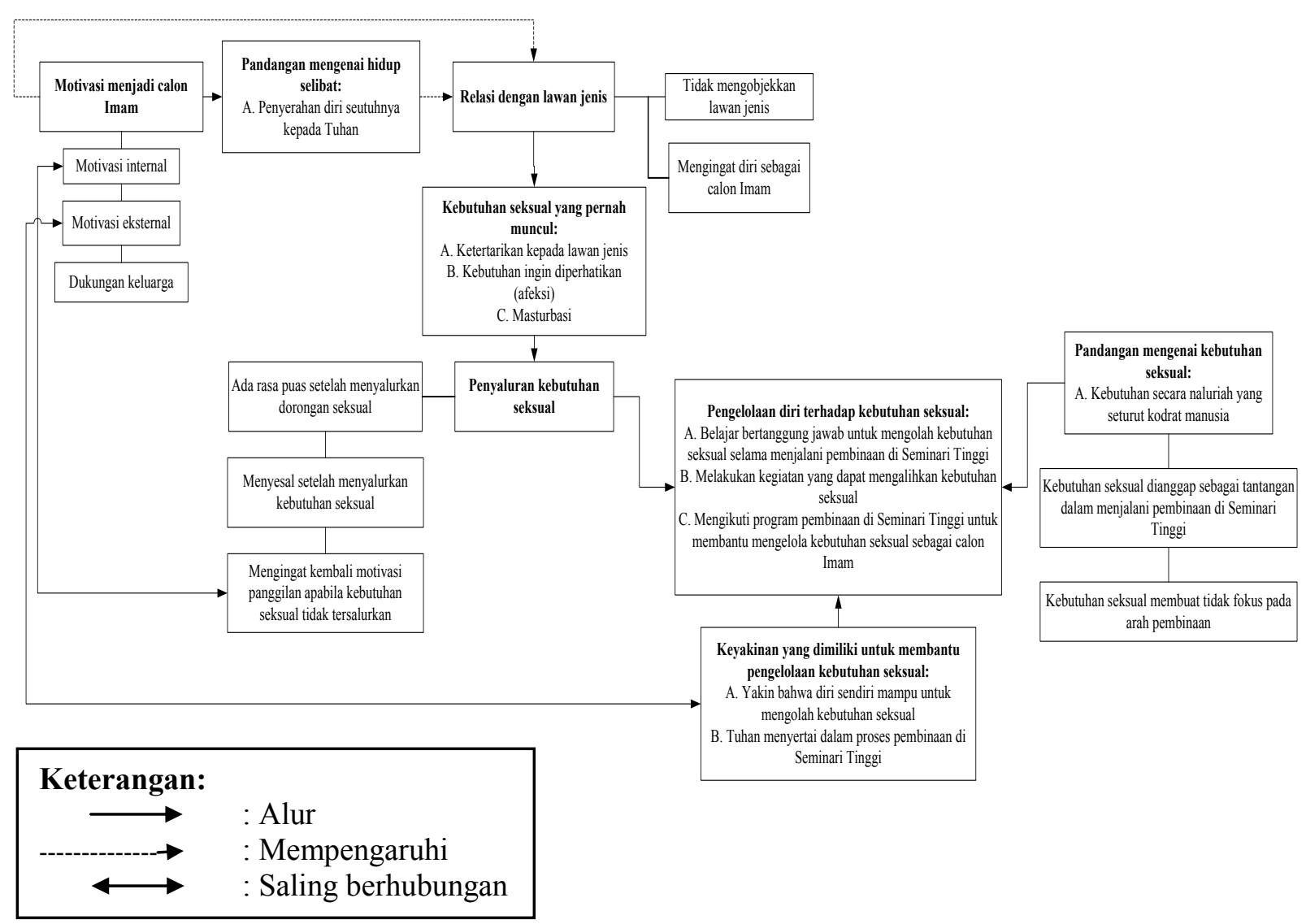

\section{Motivasi menjadi calon imam}

Berdasarkan hasil pengambilan data yang telah dilakukan, kedua informan sama-sama memiliki motivasi internal dan eksternal. Motivasi internal kedua informan berasal dari dalam diri. Kedua informan tertarik menjadi seorang calon Imam karena dorongan dari Tuhan yang muncul dari dalam diri serta ketertarikan dengan perayaan ekaristi. Motivasi eksternal kedua informan muncul karena terinspirasi dengan sosok Romo yang pernah berkarya di Paroki mereka masing-masing. Pengalaman kedua informan saat bersama dengan umat saat berpastoral juga menguatkan panggilan mereka bahwa umat di Keuskupan masing membutuhkan figur dan pelayanan dari seorang Imam. Dukungan dari keluarga juga menyertai kedua informan untuk menjadi seorang calon Imam.

Motivasi sendiri adalah faktor-faktor yang mengarahkan dan memberi energi pada perilaku manusia (Feldman, 2011: 309). Sebuah hasil penelitian yang dilakukan oleh (Charlys \& Kurniati, 2007: 38) menyimpulkan bahwa menjalani hidup selibat harus dijalankan dengan apa yang membuat seorang biarawan terpanggil untuk melayani Tuhan, 
salah satunya adalah motivasi menjadi calon Imam. Melalui hasil penelitian tersebut, peneliti melihat bahwa motivasi menjadi calon Imam adalah sebuah hal yang wajib ditinjau kembali, agar frater dapat menjalankan dan menghadapi setiap tantangan terkait dengan hidup selibat, termasuk pengelolaan kebutuhan seksualnya sendiri.

\section{Pandangan mengenai hidup selibat}

Dalam menjalani hidup selibat, kedua informan memaknai bahwa hidup selibat adalah lebih dari sekedar tidak menikah, namun memberikan diri seutuhnya, baik jasmani maupun rohani kepada Tuhan. Informan D mengganggap hidup selibat atau kaul kemurnian berhubungan dengan relasi. Informan J mengemukakan bahwa menjalani hidup selibat bukan berarti tidak merasakan jatuh cinta, namun merasakan dan mampu mengolahnya agar mengatakan 'tidak'. Konsili Vatikan II (1962-1965) menegaskan kembali posisi Katolik Roma tentang pentingnya hidup selibat. Hal ini menegaskan bahwa para imam atau calon Imam yang selibat memiliki 'hati yang tidak terbagi', mampu memberi diri lebih banyak, melayani lebih banyak, dan melakukan aktivitas dan karyanya untuk Tuhan (Abbas,dalam Sweeney, 2010: 4. Hal ini didukung dengan pernyataan informan D:

"Kalo menurut saya sendiri ya, misalnya ada seorang Pendeta atau yang boleh menikah gitu, kalo dinalar misal orang menikah itu lebih memikirkan gimana istri atau anaknya, jadi tidak secara utuh"

\section{Relasi dengan lawan jenis}

Dalam menjalin relasi dengan lawan jenis, kedua informan pernah memiliki perasaan suka dan jatuh cinta. Informan $\mathbf{J}$ merasakan jatuh cinta kepada lawan jenis saat ia menjalani pembinaan di Seminari Menengah, namun tidak sampai berpacaran. Informan J juga pernah mengungkapkan perasaan jatuh cinta kepada lawan jenis yang ia sukai dan lawan jenis tersebut menolak karena ia teringat bahwa informan $\mathbf{J}$ adalah seorang calon Imam. Setelah direnungkan, ternyata perasaan jatuh cinta yang informan $\mathrm{J}$ rasakan bukanlah aktualisasi dirinya untuk memperhatikan lawan jenis tersebut. Informan D pernah menyukai lawan jenis, namun ia menduga bahwa perasaan suka itu hanya muncul sementara saja. Dalam menyikapi hal tersebut, informan D menganggap bahwa lawan jenis adalah rekan yang setara. Kedua informan mengingat bahwa status dan motivasi panggilan mereka adalah menjadi seorang calon Imam, maka kedua informan tersebut membatasi diri dalam menjalin relasi dengan lawan jenis. Kedua informan juga memiliki pandangan bahwa jika menjalin relasi yang lebih intim dengan lawan jenis, maka lawan jenis hanya dianggap sebagai pengobjekkan nafsu saja. Maka, kedua informan lebih menghargai dan menghormati lawan jenis. Menurut Patores Dabo Vobis (KWI, 1992: 87), seorang calon Imam sebaiknya memiliki kematangan afektif yang bijaksana, mampu mengelakkan segala sesuatu yang mengancamnya, dan mampu mengenakan sikap menghormati dan menghargai dalam hubungan pribadi antara pria dan wanita.

\section{Kebutuhan seksual yang muncul}

Kebutuhan seksual yang pernah muncul dan dialami oleh kedua informan selama menjalani pembinaan di Seminari Tinggi. Kebutuhan seksual yang dialami oleh kedua informan adalah masturbasi. Masturbasi muncul akibat stimulus fisik atau rangsangan dari perempuan. Selain rangsangan fisik, rangsangan lain yang memicu kegiatan masturbasi adalah menonton film dengan adegan vulgar. Kebutuhan seksual lain yang muncul pada informan $J$ adalah memikirkan tubuh perempuan. Bila melihat lawan jenis yang memperlihatkan sisi sensitif dari tubuhnya, maka pikiran mesum akan muncul. Saat informan $\mathrm{J}$ memikirkan hal tersebut, terkadang dorongan untuk masturbasi muncul. Laki-laki dapat terangsang secara seksual oleh berbagai rangsangan, termasuk rangsangan taktil yang 
dilakukan oleh pasangan mereka, rangsangan visual, atau fantasi seksual. Terlepas dari sumber rangsangan, respons seksual pria, ereksi, dan ejakulasi dapat terjadi secara refleks (Rathus, Nevid \& Rathus, 2011: 121). Hal ini dibuktikan dengan kutipan wawancara berikut:

"Kadang kalo melihat cewek yang seksi atau memperlihatkan bentuk tubuhnya yang sensitif, pikiran mesum itu muncul."

"Nah terus aktulisasinya ya memikirkan itu tapi juga pernah muncul ingin masturbasi"

Informan D menganggap bahwa masturbasi adalah tindakan yang bodoh untuk dilakukan karena terlalu mengedepankan nafsu dan kurang kontrol atas diri sendiri. Berikut ini adalah kutipan wawancara yang mendukung pernyataan tersebut:

"Pernah, karena itu wajar"

"Dalam pandangan saya, itu tindakan yang kurang baik karena hanya berdasarkan pada nafsu-nafsu itu"

"Kadang dilakukan, kadang tidak, maksudnya dipikir dua kali, melakukan tindakantindakan yang represif, yang bertentangan dengan kemurnian, ya masturbasi dan sebagainya"

"Bagiku itu tindakan yang bodoh"

"Karena terlalu mengedepankan nafsu, ketika aku terlalu mengikuti nafsu, berarti kontrol atas diri itu kurang."

Kebutuhan seksual lain yang sering muncul pada informan $\mathrm{J}$ adalah kebutuhan ingin selalu diperhatikan, terutama oleh lawan jenis. Kebutuhan seksual yang seringkali muncul pada informan D adalah ketertarikan dengan lawan jenis. Ketertarikan itu muncul diawali dengan perasaan suka pada lawan jenis dan merasa ada kecocokan. Berikut adalah kutipan wawancara yang mendukung pernyataan tersebut:

"Lebih tepatnya ketertarikan dengan lawan jenis"

"Diawali dengan perasaan suka dengan seseorang, beda lawan jenis, merasa ada kecocokan"

\section{Penyaluran Kebutuhan Seksual}

Bila dorongan kebutuhan seksual tersalurkan, maka akan timbul rasa puas. Itulah yang dialami informan $\mathrm{J}$ saat menyalurkan dorongan masturbasi. Setelah merasa puas, muncul perasaan menyesal setelah menyalurkan kebutuhan seksual tersebut. Informan D merasa menyesal saat melakukan masturbasi jika berlandaskan pada kenikmatan semata dan tidak bisa dimaknai sehingga timbul perasaan kecewa. Ketika seorang laki-laki memikirkan aktivitas seksual, gambar, keinginan, dan fantasi seksual, maka sel yang ada di dalam korteks serebral akan menafsirkan informasi sensorik tersebut untuk mengaktifkan atau mematikannya. Sel ini akan mengirim pesan melalui saraf tulang belakang yang mengirimkan darah ke alat genital dan akhirnya menimbulkan ereksi. Setelah hal ini terjadi, korteks serebral pun juga dapat berfungsi untuk menyadarkan apakah aktivitas seksual tersebut merupakan sesuatu yang tepat atau tidak tepat, dapat menenangkan atau membuat semakin cemas, dan menimbulkan perasaan bersalah atau kepuasan (Rathus, Nevid \& Rathus, 2011). Setelah menyadari bahwa masturbasi itu salah, informan J mengaku dosa kepada Romo untuk menyadari dosa-dosa yang ia perbuat. Bila kebutuhan seksual tidak tersalurkan dengan baik, informan D diam, merenung, dan bermeditasi untuk mengingat motivasi panggilan. Berikut kutipan yang mendukung pernyataan tersebut:

"Ya, baru kemudian"

"Akhirnya ya saya mengaku dosa. Saya satu bulan sekali rutin mengaku dosa. Mengaku dosa membantu saya untuk menyadari dosa-dosa saya." (Informan J)

“Diem, merenung, bermeditasi, penjernihan mengingat motivasi panggilan.” (Informan D) 


\section{Pengelolaan diri terhadap kebutuhan seksual}

Kedua informan menganggap bahwa kebutuhan seksual bisa menjadi tantangan dalam menjalani pembinaan di Seminari Tinggi apabila tidak diolah dengan baik. Informan D merasa bahwa kebutuhan seksual yang muncul kadang-kadang mengganggu karena membuat tidak fokus pada arah pembinaan di Seminari Tinggi. Pengelolaan diri terhadap kebutuhan seksual yang dialami benar-benar diolah selama menjalani pembinaan di Seminari Tinggi, agar tidak menjadi masalah bagi orang lain. Kedua informan mengalihkan kebutuhan seksual yang muncul dengan melakukan kegiatan-kegiatan lain yang membantu mengalihkan kebutuhan seksual, seperti berolahraga, mendengarkan musik, mengerjakan tugas, makan, jalan-jalan dan membaca buku. Dalam hal ini, kedua informan menerapkan sublimasi. Sublimasi adalah tindakan mengarahkan dorongan seksual kepada suatu tindakan atau kegiatan yang lain, seperti kerja, melakukan karya sosial, seni, dan sebagainya. Biasanya, tindakan sublimasi dilakukan karena bertentangan dengan nilai yang ingin dikejar (William Kraft dalam dalam Suparno, 2007: 85). Selain itu, kedua informan juga mengikuti program pembinaan di Seminari untuk membantu menemukan pengelolaan yang efektif terhadap kebutuhan seksual yang muncul. Program-program tersebut adalah bimbingan rohani dan kepribadian, rekoleksi, retret, konferensi, dan penilaian correctio fraterna. Berikut kutipan wawancara yang mendukung pernyataan tersebut:

Bimbingan rohani ya fokusnya ke pengolahan rohani, kalo kepribadian ya fokusnya ke pengolahan pribadi, kematangan, kedewasaan dan mencakup kebutuhan seksual jika mau diceritakan"

Rekoleksi, retret, kan ada tema-temanya yang berhubungan dengan seksualitas."

"Konferensi, pertemuan bersama yang membahas tentang tema-tema yang sesuai dengan arah pembinaan Seminari”

"Diakhir pembinaan ada yang namanya penilaian correctio fraterna, mengkoreksi saudara kita"

\section{Keyakinan yang dimiliki untuk membantu proses pengelolaan kebutuhan seksual}

Kedua informan masing-masing memiliki keyakinan untuk membantu proses pengelolaan kebutuhan seksual. Informan $\mathbf{J}$ yakin dengan akal budi dan kehendak bebasnya untuk mengontrol dan mengolah kebutuhan seksual yang muncul. Bimbingan dan pengalaman Romo serta masukan dari teman-teman juga membantunya mengolah kebutuhan seksual dengan baik. Selain itu, infoman percaya bahwa Tuhan selalu menyertaimemberikan rahmatNya untuk mengelola kebutuhan seksual demi pembinaan diri yang lebih baik. Informan D memiliki keyakinan bahwa dirinya mampu untuk mengatasi kebutuhan seksual yang dialami. Selain itu pengetahuan mengenai kebutuhan seksualitas yang dimiliki masingmasing informan juga membantu untuk menanggapi kebutuhan seksual. Informan J membaca literatur yang berkaitan dengan dorongan seksual, sehingga informan $\mathbf{J}$ memperoleh sudut pandang ilmu lain dalam menanggapi kebutuhan seksual. Informan D memperoleh pengetahuan mengenai kebutuhan seksualitas dan cara penyalurannya saat informan berada di Kelas 3 SMP, sehingga hal tersebut mempengaruhi pandangan informan terkait kebutuhan seksual.

Penelitian ini menemukan bahwa motivasi panggilan untuk menjadi seorang Imam menguatkan mereka dalam mengelola kebutuhan seksual. Apabila kebutuhan seksual tidak tersalurkan dengan baik, kedua informan kembali mengingat motivasi panggilan yang telah mereka jalani. Keyakinan yang mereka miliki dalam mengelola kebutuhan seksualnya juga berhubungan dengan motivasi panggilan yang telah tertanamkan dalam diri kedua informan. Dalam hal ini, motivasi panggilan untuk menjadi seorang calon Imam membantu mereka untuk mengelola kebutuhan seksual yang dialami.

Hasil penelitian ini juga memiliki kesamaan dengan hasil penelitian yang dilakukan oleh Pranoto (2014), bahwa ada beberapa hal yang mendukung pengelolaan kebutuhan seksual 
secara tepat, yakni motivasi panggilan menjadi seorang Imam, keyakinan yang dimiliki untuk mengelola kebutuhan seksual dan pandangan mengenai kebutuhan seksual. Selain itu, kedua informan melakukan sublimasi, yaitu mengarahkan dorongan seksual pada tindakan atau kegiatan lain, seperti membaca buku, berolah raga, mengerjakan tugas, dan mendengarkan musik. Dalam hal ini, kedua informan melakukan kegiatan untuk mengalihkan kebutuhan seksual yang muncul

Melalui hasil analisis pada penelitian ini, peneliti menemukan beberapa perbedaan dan persamaan pada tiap informan dalam menghadapi kebutuhan seksualnya. Perbedaan yang menonjol pada kedua informan tersebut adalah pengalaman dalam mengenal lawan jenis. Informan J pernah memiliki relasi yang cukup dekat dengan lawan jenis, sehingga cenderung lebih ekspresif dalam menyalurkan kebutuhan seksual, salah satunya dengan masturbasi. Informan $\mathrm{D}$ belum pernah memiliki relasi yang dekat dengan lawan jenis, sehingga cenderung tidak terlalu berfokus dengan kebutuhan seksual dan mengalihkannya dengan kegiatan yang lain. Perbedaan tersebut menjadi sebuah hal yang khas dan unik pada tiap informan. Kedua informan memandang bahwa hidup selibat merupakan penyerahan diri seutuhnya kepada Tuhan, sehingga dalam menjalin relasi dengan lawan jenis, kedua informan dapat membatasi diri. Kedua informan juga memandang bahwa kebutuhan seksual adalah kebutuhan secara alamiah dan naluriah yang merupakan bawaan dari manusia, namun manusia dapat mengontrolnya. Pandangan tersebut yang menuntun kedua informan untuk mengontrol dan mengelola kebutuhan seksual melalui kegiatan yang dapat membantu untuk mengalihkan kebutuhan seksual.

\section{Simpulan dan Saran}

Frater merupakan panggilan bagi laki-laki beragama Katolik yang memutuskan untuk hidup selibat dengan menyerahkan diri sepenuhnya kepada Tuhan. Bagi laki-laki yang memilih untuk menjadi seorang frater, berarti dirinya telah memutuskan untuk mengabdikan hidupnya hanya kepada Tuhan dan tinggal di dalam Seminari hingga akhir hidupnya, sehingga ia harus secara sukarela meninggalkan setiap kehidupan duniawinya di luar Seminari. Selain itu, proses pembinaan yang dijalani para frater bertujuan untuk persiapan menjadi seorang Imam atau Pastor Katolik dengan menjalani hidup selibat. Hidup selibat atau kaul kemurnian ini harus dilakukan, ditaati, dan dihayati oleh setiap frater yang menjalani pilihan hidupnya, meskipun tidak mudah untuk menjalaninya. Kehidupan perkuliahan yang dijalani, interaksi dengan lawan jenis, serta pembinaan hidup rohani yang lebih dalam bukanlah suatu hal yang mudah untuk dilakukan dan dihayati oleh masing-masing frater. Hal tersebut merupakan suatu kewajiban, tetapi seorang frater juga manusia biasa yang sama seperti manusia lainnya. Mereka juga mengalami dan merasakan dorongan kenikmatan duniawi dengan berbagai macam kebutuhan, salah satunya adalah kebutuhan seksual.

Kebutuhan seksual juga muncul dan dialami oleh seorang frater. Kedua informan pernah merasakan dorongan seksual selama menjalani pembinaan di Seminari Tinggi. Kebutuhan seksual tersebut dianggap sebagai tantangan dan membuat informan tidak fokus dalam menjalani pembinaan di Seminari Tinggi. Kebutuhan seksual yang muncul pada kedua informan adalah kebutuhan seksual fisik (mastubasi), pemikiran yang tidak senonoh (mesum) dan kebutuhan afeksi (ingin diperhatikan dan tertarik pada lawan jenis). Kebutuhan ini muncul karena adanya rangsangan dari lawan jenis, baik secara fisik maupun visual (menonton film dengan adegan vulgar), serta adanya perasaan tertarik dan ingin diperhatikan oleh lawan jenis.

Kedua informan tersebut menyalurkan kebutuhan seksual yang muncul dan menghasilkan rasa puas karena dorongan seksual tersampaikan. Setelah menyalurkan dorongan seksual tersebut, kedua informan merasa menyesal karena melakukan tindakan yang salah dan hanya berdasarkan nafsu dan kenikmatan saja. Bila dorongan seksual tidak 
dapat disalurkan dengan baik, maka kedua informan akan mengingat kembali motivasi panggilan untuk menjadi seorang calon Imam.

Selama menjalani pembinaan di Seminari Tinggi, kedua informan benar-benar belajar untuk mengelola kebutuhan seksual yang muncul agar tidak menjadi masalah bagi orang lain. Penelitian ini menemukan bahwa kebutuhan seksual dapat dikelola dengan kegiatan-kegiatan yang dapat membantu mengalihkan dorongan seksual untuk disalurkan, seperti makan, berolahraga, mendengarkan musik, jalan-jalan, mengerjakan tugas, dan membaca buku. Selain itu, informan juga mengikuti program pembinan yang ada di Seminari seperti bimbingan rohani dan kepribadian, rekoleksi, retret, dan konferensi untuk membantu menyadari posisi kedua informan sebagai seorang calon Imam dan membantu menemukan cara pengelolaan yang efektif untuk mengelola kebutuhan seksual.

Kedua informan juga memiliki keyakinan untuk mengelola kebutuhan seksual dan berhubungan dengan motivasi panggilannya sebagai seorang Imam. Kedua informan yakin bahwa mereka mampu menyadari dan mengelola kebutuhan seksual tersebut serta meyakini bahwa Tuhan akan senantiasa menyertai proses pembinaan mereka di Seminari Tinggi. Dalam hal ini, motivasi panggilan menjadi seorang Imam, keyakinan yang dimiliki untuk mengelola kebutuhan seksual dan pandangan mengenai kebutuhan seksual juga membantu kedua informan dalam mengelola kebutuhan seksual yang dialami.

Informan dari penelitian ini dan frater lainnya, diharapkan dapat menyadari kebutuhan seksual yang muncul dan mulai belajar untuk mengelolanya secara tepat agar tidak menjadi 'batu sandungan' bagi informan maupun orang lain. Seminari Tinggi sebagai tempat pembinaan para frater, diharapkan dapat memberikan dukungan dan pembinaan mengenai pengelolaan kebutuhan seksual yang tepat. Hal ini perlu diberikan melalui program-program pembinaan di Seminari dengan mengangkat tema kebutuhan seksual, sehingga para frater dalam mengambil tindakan yang tepat untuk mengelola kebutuhan seksualnya.

Berdasarkan hasil penelitian ini, ada beberapa saran dari peneliti yang bisa dijadikan masukan untuk penelitian selanjutnya. Penelitian selanjutnya diharapkan mampu menjadi sumber referensi bagi peneliti selanjutnya mengenai pengelolaan kebutuhan seksual pada kelompok biarawan dan biarawati. Penelitian selanjutnya juga diharapkan dapat meneliti pengelolaan kebutuhan seksual pada biarawan (bruder) atau Romo (imam Katolik), karena tentunya akan ada perbedaan tantangan dan cara pengelolaan yang dilakukan karena berhubungan langsung dengan umat dan sudah menjalani tiga kaul menurut Kitab Hukum Kanonik. Sebelum melakukan penelitian, peneliti selanjutnya dianjurkan untuk dapat mengatur waktu lebih baik (menyesuaikan dengan jadwal informan) serta membuat daftar pertanyaan yang lebih terbuka agar data yang diperoleh lebih kaya dalam proses pelaksanaan pengambilan dan pengolahan data.

\section{Referensi}

Charlys \& Kurniati, N.M.T. (2007). Makna hidup pada biarawan. Depok: Jurnal Psikologi. Creswell, J. W. (2013). Research design: quantitative, qualitative, and mixed method approaches. Yogyakarta: Pustaka Belajar.

Departemen Dokumentasi dan Penerangan KWI. (1992). Patores dabo vobis (Gembalagembala akan kuangkat bagimu). Bogor: SMT Grafika Mardi Yuwana.

Feldman, R.S. (2011). Understanding psychology (edisi ke 10). New York: McGraw-Hill.

Fisher, T.D., Moore, Z.T., \& Pittinger, Mary J. (2012). Sex on the brain?: an examination of frequency of sexual cognitions as a function of gender, erotophilia, and social desirability. The Journal of Sex Research. Doi: 10.1080/00224499.2011.565429. $\begin{array}{lllll}\text { Diunduh pada } & \text { Mei } & 2018 \text { melalui }\end{array}$ 
http://libgen.io/scimag/ads.php?doi=10.1080\%2F00224499.2011.565429\&downloadna $\underline{\text { me }}$

Hurlock, E. B. (1996). Psikologi perkembangan: suatu pendekatan sepanjang rentang kehidupan. Edisi kelima. Jakarta: Erlangga

Konferensi Waligereja Indonesia. (2016). Kitab hukum kanonik (Codex iuris canonix). Edisi resmi bahasa Indonesia. Jakarta: Konferensi Waligereja Indonesia.

McDevitt, P.J. (2012). Sexual and intimacy health of roman catholic priests. Journal of Prevention \& Intervention in the Community, 40: 208-218. DOI: 10.1080. Diunduh melalui

http://libgen.io/scimag/ads.php?doi=10.1080\%2F10852352.2012.680413\&downloadna $\underline{\text { me }}$

Pranoto, H. C.H. (2014). Pengelolaan kebutuhan seksual biarawati yang tetap mempertahankan kaul kemurniannya. Skripsi. Surabaya: Fakultas Psikologi Universitas Katolik Widya Mandala Surabaya.

Prasetya, F. M. (1992). Psikologi hidup rohani 2. Yogyakarta: Kanisius

Rathus, S.A., Nevid, J.S. \& Rathus, L.F. (2011) Human sexuality in a world of diversity. Edisi ke-8. USA: Pearson Education, Inc.

Santrock, J. W. (1999). Life span development. Edisi ketujuh. United States: McGraw-Hill

Smith, J. A. (2009). Psikologi kualitatif: panduan praktis metode riset. (Alih bahasa: B. Santosa. Yogykarta: Pustaka Pelajar.

Suparno, P. (2006). Spiritualitas dan seksualitas dalam hidup membiara. Rohani menjadi semakin insani: Menopang impian terpendam. Yogyakarta: Kanisius.

Suparno, P. (2007). Seksualitas kaum berjubah. Yogyakarta: Kanisius.

Sweeney, G. (2010). Practical ways to help priests remain chaste. Artikel ilmiah. The Institute for the Psychological Sciences 